ogist's Handbook, The Student Political Scientist's Handbook, and The Student Economist's Handbook.

The guide under review differs from most in that it emphasizes bibliographic tools and techniques necessary for research, rather than stressing descriptions of journals, theories, etc. While such information is provided, it is not included at the expense of bibliographic information. Traditional topics, such as the card catalog, indexes/abstracts, bibliographies, and government documents, are discussed, as are archival research and computer literature searching.

Regarding the card catalog and government documents, one statement is somewhat misleading. Simpson indicates that "The only separately published items generally not [emphasis in original] included in the catalogs are those special collections of documents maintained on microform" (p.87). Many libraries, especially those employing SuDocs classification, do not catalog documents in any format, not only microform. This criticism notwithstanding, this is an excellent guide that will be of use to researchers and students in a wide range of social science disciplines.-David R. McDonald, Social Science Bibliographer, Farrell Library, Kansas State University, Manhattan.

\section{OTHER PUBLICATIONS OF INTEREST TO ACADEMIC LIBRARIANS}

Ackroyd, Ted J. Health and Medical Economics: A Guide to Information Sources. Economics Information Guide Series, v.7. Detroit: Gale, 1977. 149p. \$18.00. LC 7317567. ISBN 0-8103-1390-1.

Allison, A. F., and Goldsmith, V. F. Titles of English Books and of Foreign Books Printed in England: An Alphabetical Finding-list by Title of Books Published Under the Author's Name, Pseudonym or Initials. Volume II, 1641-1700. Hamden, Conn.: Archon Books, 1977. 318p. $\$ 30.00$. LC 76-21206. ISBN 0-208-01625-2.

American Library Association. Ad Hoc Committee to Revise the ALA Personnel Organization and Procedure Manuals. The Personnel Manual. Chicago: American Library
Assn., 1977. 39p. LC 77-5539. ISBN 0-83890239-1.

American Library Association. Book Catalogs Committee. Guidelines for Book Catalogs. Chicago: American Library Assn., 1977. 45p. LC 77-1240. ISBN 0-8389-3190-1.

Asian American Librarians' Caucus. Bibliography Committee. Asian Americans: An Annotated Bibliography for Public Libraries. Chicago: American Library Assn., 1977. 47p. LC 77-8014. ISBN 0-8389-5507-X.

Intended as a basic list of Asian American titles for purchase by public libraries. Included are adult and children's titles covering the major Asian American groups: Chinese Americans, Japanese Americans, Korean Americans, and Filipino Americans.

Association for Educational Communications and Technology. Copyright and Educational Media: A Guide to Fair Use and Permissions Procedures. Washington, D.C.: Association for Educational Communications and Technology and the Association of Media Producers, 1977. 28p. $\$ 3.95$ ( $\$ 2.95$ to AECT members). ISBN 0-89240-004-8.

Balachandran, M. A Guide to Trade and Securities Statistics. Ann Arbor, Michigan: Pierian Press, 1977. 185p. \$14.95. LC 77-73818. ISBN 0-87650-07-7.

Provides subject analysis of thirty serials in the area of trade and securities statistics.

Balachandran, Madhava. A Subject Approach to Business Reference Sources. Univ. of Illinois Graduate School of Library Science Occasional Papers, no. 128. Champaign, Ill.: Graduate School of Library Science, Univ. of Illinois, 1977. 45p. $\$ 2.00$.

Bayliss, Gwyn M., comp. Bibliographic Guide to the Two World Wars: An Annotated Survey of English-Language Reference Materials. New York: Bowker, 1977. 578p. $\$ 30.00$. LC 77-70292. ISBN 0-85935-013-4.

Guide to selected guides and publications about the two world wars. Each entry contains full bibliographic information on the publication.

Choix et acquisition des documents au Québec. Volume 1: Principes et applications. In collaboration and under the direction of Michel Thériault. Montréal: ASTED (Association pour l'avancement des sciences et des techniques de la documentation), 1977. 293p. $\$ 15.00$.

Clarke, Thomas E. $R$ \& $D$ Management Bibliography, 1976. Ottawa, Ont.: The Innovation Management Institute of Canada, 1977. 183p. $\$ 17.50$.

Contains references to articles, books, and conference proceedings in the area of research and development management in industrial and government laboratories. 


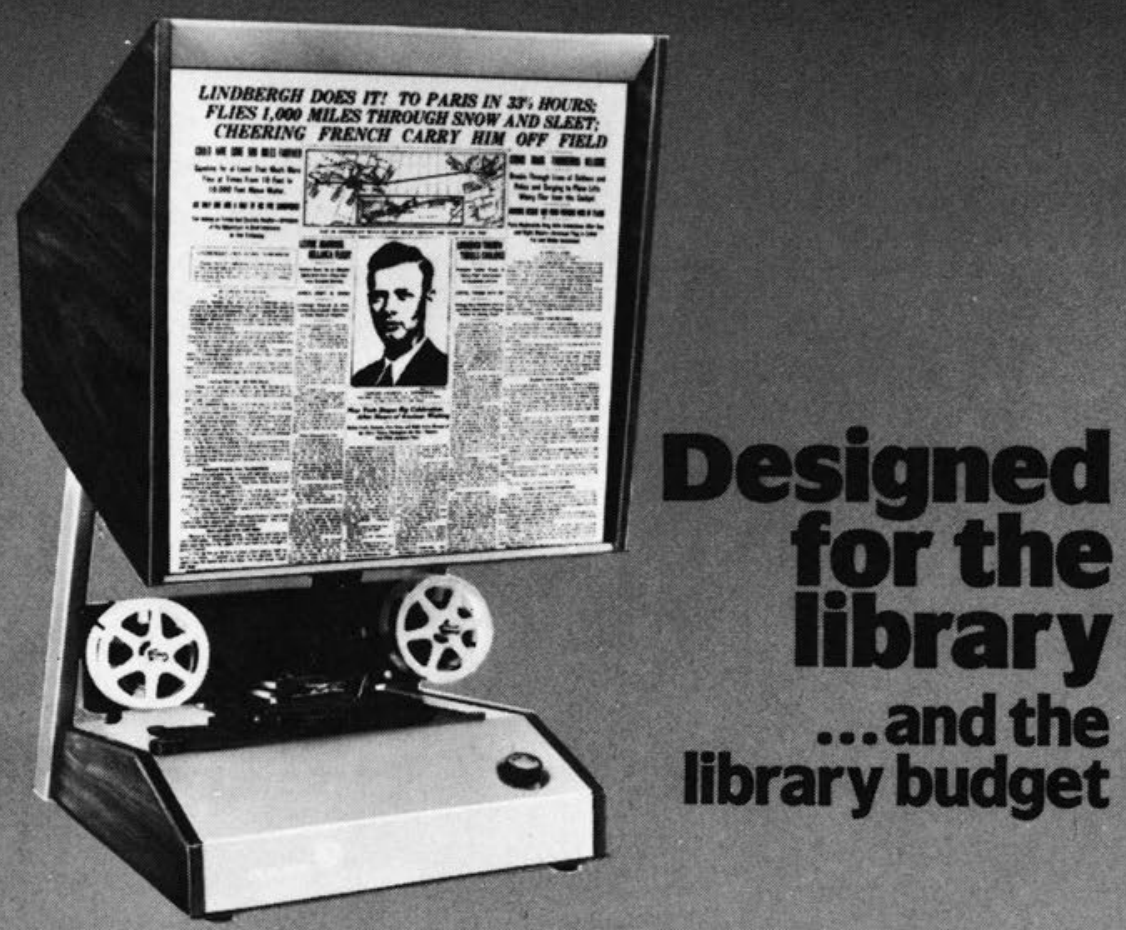

Our Microreaders cost less ... much less. For the price of most competitive readers you can purchase two Dukane readers without sacrificing quality or performance. Dukane offers motorized or manual operation for both $35 \mathrm{~mm}$ and $16 \mathrm{~mm}$ roll film - with adaptors available for viewing fiche and aperture cards. The Microreader is designed for loading from a seated position with all controls conveniently located. Images are clear and sharply defined over the entire screen even under brightly lighted conditions. Dukane Microreaders feature rugged high quality construction designed to withstand rough daily use.

Dukane Microreaders carry a one year warranty on parts and labor and are UL Approved. GSA Contract GS-OOS-45048

Suggested Retail Prices

Dukane Manual Microreader

$18 \mathrm{X} \ldots \ldots \ldots . \$ \$ 55.00$

Send for additional information.

Dukane Motorized

Microreader, $18 \mathrm{X} \ldots \$ 680.00$

Name

Address

City

State Zip.

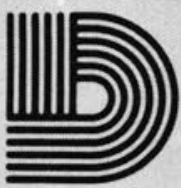

DUKANE CORPORATION/AUDIO VISUAL DIVISION/ DEPT. CRL-II/ST. CHARLES, ILLINOIS 60174 


\section{4 / College d Research Libraries • November 1977}

Consumers Index to Product Evaluations and Information Sources 1976 Annual. Editorin-chief, C. Edward Wall. Ann Arbor, Mich.: Pierian Press, 1977. 263p. Quarterly plus annual cumulation $\$ 69.50$. LC 74-25361. ISBN 0-87650-080-7.

Continuing Education: A Guide to Career Development Programs, 1977. New York: Gaylord Professional Publications; Neal-Schuman Publishers, 1977. 696p. \$39.95. LC 7771331. ISBN 0-915794-10-1.

"A guide to programs and learning centers that provide advanced training in the thousands of jobs and professional specialities encompassed in more than 150 major career areas."

The Corning Flood: Museum Under Water. Editor, John H. Martin. Associate editor, Charleen K. Edwards. Corning, N.Y.: The Corning Museum of Glass, 1977. 60p. LC 77-73627. ISBN 087290-063-0.

Describes the restoration of the Corning $\mathrm{Mu}-$ seum of Glass after the flood in June 1972 and offers suggestions for disaster planning the museum gained from the experience.

Crouch, Milton, and Raum, Hans, comps. Directory of State and Local History Periodicals. Chicago: American Library Assn., 1977. 124p. LC 77-4396. ISBN 0-8389-02464.

Demers, Jacques. Gestion des documents audiovisuels dans les bibliothèques des collèges francophones du Québec. Publications de l'École de bibliothéconomie, no. 6. Montréal: ASTED (Association pour l'avancement des sciences et des techniques de la documentation), 1977. 307p. \$20.00.

Detroit. Public Library. Kate Greenaway: A Catalogue of the Kate Greenaway Collection, Rare Book Room, Detroit Public Library. Compiled by Susan Ruth Thomson. Detroit: Wayne State University Press, 1977. 211 . $\$ 30.00$. LC 77-5222. ISBN $0-8143$ 1581-X.

Educators Guide to Free Filmstrips. 29th ed. Compiled and edited by Mary Foley Horkheimer and John C. Diffor. Randolph, Wis.: Educators Progress Service, 1977. 174p. $\$ 10.00$. LC 50-11650. ISBN 0-87708-072-0.

Foreign Trade Marketplace. Edited by George J. Schultz. Detroit: Gale, 1977. 662p. \$48.00. LC 76-20342. ISBN 0-8103-0981-5.

Consists of two major parts. Part One gives an overview of the mechanics of international trade from the standpoint of American companies. Part Two is a directory of business contacts, financing sources, insurance transport services, and a variety of other marketing and supporting services or references.

Great Treasury of Western Thought: A Compendium of Important Statements on Man and His Institutions by The Great Thinkers in Western History. Edited by Mortimer J. Adler and Charles Van Doren. New York: Bowker, 1977. 1,771p. \$29.95. LC 77-154. ISBN 0-8352-0833-8.

Twenty chapters containing quotations from biblical times to modern times on basic human themes. Some of the subjects covered are man, family, love, ethics, economics, and liberty and equality.

Hillard, James M. Where to Find More: A Handbook to Reference Service. Metuchen, N.J.: Scarecrow Press, 1977. 122p. \$6.00. LC 77-6406. ISBN 0-8108-1039-5.

Supplements and updates the author's Where to Find What, published in 1975. Describes reference sources under 225 subject headings.

Johnson, Steven L. Guide to American Indian Documents in the Congressional Serial Set: 1817-1899. The Library of American Indian Affairs. N.Y.: Clearwater Publishing Company, 1977. 503p. \$30.00. LC 75-45321. ISBN 0-88354-107-6.

Includes annotations for 10,000 documents found in the serial set covering the American Indian. "For each document the entry provides the Serial Set number, date, source, title and subjects covered."

Kurth, William H., and Zubatsky, David S. Recommended Procedures for the Internal Financial Auditing of University Libraries. St. Louis, Mo.: Washington University Libraries, 1977. 96p. (Photocopy for $\$ 3$ available from Washington University Libraries, St. Louis, MO 63130.)

Lyman, Helen Huguenor. Literacy and the $\mathrm{Na}$ tion's Libraries. Chicago: American Library Assn., 1977. 212p. \$12.50. LC 77-4450. ISBN 0-8389-0244-8.

Discusses "the procedure to be followed by public librarians in developing their programs to serve the illiterate." Sample programs, funding sources, and kinds of material needed for the literacy collection are given.

Markotic, Vladimir, and Petrunic, T., comps. and eds. Ethnic Directory of Alaska, Hawaii, Oregon and Washington. Calgary, Alberta: Western Publishers, 1977. 81p. (Available from Western Publishers, P.O. Box 30193, Station "B," Calgary, Alberta, Canada.)

Markotic, Vladimir, comp. and ed. Assisted by T. Petrunic. Ethnic Directory of California. Calgary, Alberta: Western Publishers, 1977. 168p. (Available from Western Publishers, P.O. Box 30193, Station "B," Calgary, Alberta, Canada.)

Media Review Digest 1977. Editor-in-chief, C. Edward Wall. Managing editor and head cataloger, Elinor J. Schwartz. Ann Arbor, Michigan, Pierian Press, 1977. 542p. \$79.50/ 
yr. plus one supplement. LC 73-172772. ISBN 0-87650-085-8.

Medical and Health Information Directory. A Guide to State, National and International Organizations, Government Agencies, Educational Institutions, Hospitals, Grant-Award Sources, Health Care Delivery Agencies, Journals, Newsletters, Review Serials, Abstracting Services, and Libraries and Information Centers. Edited by Anthony T. Kruzas. Detroit: Gale, 1977. 664p. $\$ 48.00$. LC 77-82802. ISBN 0-8103-0266-7.

National Health Insurance. Comp. and ed. by Tyrus G. Fain in collaboration with Katharine C. Plant and Ross Milloy. Public Documents Series. New York: Bowker, 1977. 554 p. $\$ 29.95$. LC $77-22947$. ISBN $0-8352$ 0960-1.

National Library of Canada. Resources Survey Division. Checklists of Law Reports and Statutes in Canadian Law Libraries, 2: United Kingdom and Irish Republic (EIRE) Law Reports. 1977. 528p. Ottawa: National Library of Canada, Resources Survey Division, 1977. 528p. $\$ 5.00$ Canada; $\$ 6.00$ other countries. ISBN 0-662-00675-5.

Prucha, Francis Paul. A Bibliographical Guide to the History of Indian-White Relations in the United States. Chicago: Univ. of Chicago Pr., 1977. 454p. $\$ 6.95$ paper. Cloth library edition: $\$ 17.50$. LC 76-16045. ISBN 0-226-68477-8 paper; ISBN 0-226-68476-8 clothbound.

Reference Sources, 1977. Edited by Linda Mark. Ann Arbor, Mich.: The Pierian Press, 1977. 430p. Priced on a sliding scale from $\$ 19.95$ to $\$ 35.00$. LC $77-79318$. ISBN 0 87650-084-X.

Current guide to reference materials reviewed in such publications as Booklist, Choice, and Library Journal. "Information for each publication includes verified main entry, full bibliographic information and price, LC headings, Dewey numbers, and annotations and review quotations from selected sources."

Rosa, Alfred F., and Eschholz, Paul A. Contemporary Fiction in America and England, 1950-1970: A Guide to Information Sources. American Literature, and World Literatures in English Information Guide Series. Detroit: Gale, 1976. 454p. \$18.00. LC 7316990. ISBN 0-8103-1219-0.

Rufsvold, Margaret I. Guides to Educational Media. 4th ed. Chicago: American Library Assn., 1977. 159p. \$5.00. LC 77-5058. ISBN 0-8389-0232-4.

"A comprehensive listing of published catalogs, currently available, which are devoted to nonprint educational media."

Rulers and Governments of the World. Volume 2, 1492-1929. Comp. by Bertold Spuler. New York: Bowker, 1977. 779p. \$45.00. LC 77-70294. ISBN 0-85935-009-6.

Alphabetical listing by country or political territory of heads of state and principal government ministers. Their place and date of birth and death are given, where the information is known.

Schorr, Alan Edward, comp. Government Documents in the Library Literature, 1909-1974. Ann Arbor, Mich.: The Pierian Press, 1976. 110p. \$6.95. LC 77-70340. ISBN 0-87650071-8.

Guide to articles, books, conference proceedings, and reviews covering all aspects of government documents librarianship.

Science Update-77. Edited by Thomas G. Aylesworth and Stanley Klein. Syracuse, N.Y.: Gaylord Professional Publications, 1977. 224p. \$50.00. ISBN 9-915794-11-X.

Essays discuss the most recent progress taking place in science research laboratories throughout the world.

Széplaki, Joseph, comp. Bibliography on Cardinal Mindszenty (1892-1975). Youngstown, Ohio: Catholic Hungarians' Sunday, 1977. 31p. $\$ 1.50+\$ .25$ postage and handling. LC 77-80152. (Available from: Catholic Hungarians' Sunday, 1739 Mahoning Ave., Youngstown, $\mathrm{OH} 44509$.

Széplaki, Joseph, comp. Hungarian Newspapers in Microform Available in the United States and Canada. Youngstown, Ohio: Catholic Hungarians' Sunday, 1977. 19p. $\$ 1.50+$ $\$ .25$ postage and handling. (Available from: Catholic Hungarians' Sunday, 1739 Mahoning Ave., Youngstown, OH 44509.)

Women's History Research Center. Female Artists Past and Present. Berkeley, Calif.: Women's History Research Center, 1974. 158 p. $\$ 6.00$ to individual women. $\$ 7.00$ to groups and institutions. (Available from Women's History Research Center, Inc., 2325 Oak St., Berkeley, CA 94708.)

A directory/bibliography of women in the visual arts. Individual women have been listed alphabetically according to the media in which they work.

Women's History Research Center. Films By and/or About Women, 1972: Directory of Filmmakers, Films, and Distributors Internationally, Past and Present. Berkeley, Calif.: Women's History Research Center, 1972. 72 p. $\$ 3.00$ to individual women. $\$ 5.00$ to groups and institutions. (Available from Women's History Research Center, Inc., 2325 Oak St., Berkeley, CA 94708.) 